\title{
Pengaruh Model Students Facilitator and Explaining Terhadap Kemampuan Membaca siswa Kelas II SD Negri 010146 Labuhan Ruku Tahun Pembelajaran 2017/2018
}

\author{
Oleh: \\ Sri Listiana Izar (srilistiana @umsu.ac.id) \\ Dosen FKIP Prodi Pendidikan Bahasa dan Sastra Indonesia, \\ Universitas Muhammadiyah Sumatera Utara
}

\begin{abstract}
ABSTRAK
Permasalahan penelitian ini adalah 1).Bagaimana pengaruh model Students Facilitator and Explaining terhadap kemampuan membaca siswa kelas II SD Negri 010146 Labuhan Ruku Tahun Pembelajaran 2017/2018. 2). Bagaiman pengaruh strategi pembelajaran ekspositoriterhadap kemampuan membaca siswa kelas II SD Negri 010146 Labuhan Ruku Tahun Pembelajaran 2017/2018. 2). Adakah pengaruh model Students Facilitator and Explaining terhadap kemampuan membaca siswa kelas II SD Negri 010146 Labuhan Ruku Tahun Pembelajaran 2017/2018. Adapun tujuan penelitian ini 1).Untuk mengetahui sejauh mana pengaruh "Students Facilitator and Explaining" terhadap kemampuan membaca siswa kelas II SD Negri 010146 Labuhan Ruku Tahun Pembelajaran 2017/2018. 2). Untuk mengetahui pengaruh strategi pembelajaran ekspositori terhadap kemampuan membaca siswa kelas II SD Negri 010146 Labuhan Ruku Tahun Pembelajaran 2017/2018. 3). Untuk mengetahui ada atau tidak pengaruh model Students Facilitator and Explaining terhadap kemampuan membaca siswa kelas II SD Negri 010146 Labuhan Ruku Tahun Pembelajaran 2017/2018. Subjek penelitian ini adalah siswa kelas 1I SD NEGRI 010146 Labuhan Ruku,yang berjumlah 2 kelas dan tiap kelas rata-rata terdiri dari 25 orang siswa maka jumlah seluruh populasi adalah 50 orang siswa.Hasil dari penelitian ini dibuktikan berdasarkan perhitungan, diketahui kemampuan sebagian siswa yang diajar dengan menggunakan model Students Facilitator and Explaining siswa banyak mendapatkan nilai 9 yaitu 36\%, artinya kemampuan sebagian besar siswa yang diajar dengan model students facilitator and explaining berada pada tingkat sangat baik. Sedangkan kemampuan membaca tanpa menggunakan model students facilitator and explaining siswa banyak mendapatkan nilai 7 sampai 8 artinya kemampuan dari sebagian besar siswa yang diajarkan tanpa model students facilitator and explaining berada pada tingkat baik.
\end{abstract}

Kata Kunci:Model Students Facilitator and Explaining,Kemampuan Membaca, 


\section{PENDAHULUAN}

\section{Latar Belakang Masalah}

Pendidikan bahasa tak lepas dari berbagai masalah, mencakup masalah-masalah linguistik atau kebahasaan dan keterampilan berbahasa.Masalah linguistik yang menjadi fokus penelitian pendidikan bahasa di antaranya adalah fenomenafenomena yang berkaitan dengan penutur bahasa dan pengguna bahasa. Masalah lain yang berhubungan dengan penelitian bahasa adalah bagaimana mengidentifikasi sifat-sifat bahasa secara model-model pengembangannya. Adapun masalah keterampilan berbahasa yang menjadi fokus penelitian bahasa mencakup keterampilan mebaca, menulis, berbicara dan menyimak. Keempat cakupan keterampilan berbahasa tersebut bukanlah satu aspek yang terpisah-pisah melainkan saling berkaitan satu dengan yang lain, yaitu membaca berkaitan erat dengan menulis atau sebaliknya, berbicara berkaitan erat dengan menyimak atau sebaliknya. Oleh sebab itu, pengajaran keterampilan berbahasa membutuhkan sebuah pengajaran yang kompleks, yang tidak hanya berdasarkan satu aspek keterampilan berbahasa saja.

Membaca adalah interaktif.Keterlibatan pembaca dan teks tergantung dengan konteks. Orang yang senang membaca suatu teks yang bermanfaat, akan menemui beberapa tujuan yang ingin dicapainya, teks yang dibaca seseorang harus mudah dipahami sehingga terjadi interaksi antara pembaca dengan teks. Rita Wati dalam (Soedarso. 2001), mengemukakan langkah-langkah membaca sebagai berikut: 1) Mengenal unsur kalimat, 2) Mengenal unsur kata, 3) Mengenal unsur huruf, 4) Merangkai huruf menjadi suku kata dan 5) Merangkai suku kata menjadi kata. Menurut Akhadiah dalam (Dwi Indri Oktaviani 2003) mengemukakan langkahlangkah pengakaran membaca permulaan sebagai berikut: 1. Menentukan tujuan

pokok bahasan yang akan di berikan., tujuan ini dapat di ambil dari GBPP. 2. 
Mengembangkan bahan pengajaran. 3. Setelah bahan pelajaran dan bahan latihan disusun, kemudian harus memikirkan bagaimana caramenyampaikan, bagaimana urutan pemberian bahan-bahannya, dan bagaimana cara mengaktifkan siswa. 4. Pada tahap latihan, guru dapat membuat kombinasi baru, baik dengan kata maupun suku kata, dan huruf.

Pengertian Student Facilitator and Explaining adalah menyajikan materi dengan mendemonstrasikan didepan siswa lalu memberikan kesempatan kepadanya untuk menjelaskan kepada rekan-rekannya merupakan makna dasar dari penggunaan model pembelajaran student facilitator and explaining dalam proses belajar mengajar. Jadi, model pembelajaran student facilitator and explaining adalah rangkaian penyajian materi ajar yang diawali dengan menyampaikan kompetensi siswa yang harus dicapai, lalu menjelaskannya dengan didonstrasikan, kemudian diberikan kesempatan pada siswa untuk mengulangi kembali untuk dijelaskan pada rekan-rekannya dan diakhiri dengan penyampaian semua materi pada siswa.

\section{Rumusan Masalah}

Adapun yang menjadi rumusan masalah dalam penelitian ini adalah :

1. Bagaimana pengaruh model Students Facilitator and Explainingterhadap kemampuan membaca siswa kelas II SD Negri 010146 Labuhan Ruku Tahun Pembelajaran 2017/2018?

2. Bagaiman pengaruh strategi pembelajaran ekspositoriterhadap kemampuan membaca siswa kelas II SD Negri 010146 Labuhan Ruku Tahun Pembelajaran $2017 / 2018 ?$

3. Adakah pengaruh model Students Facilitator and Explaining terhadap kemampuan membaca siswa kelas II SD Negri 010146 Labuhan Ruku Tahun Pembelajaran 2017/2018?

\section{Tujuan Penelitian}

Adapun tujuan dari penelitian ini sebagai berikut : 
1.Untuk mengetahui sejauh mana pengaruh "Students Facilitator and Explaining" terhadap kemampuan membaca siswa kelas II SD Negri 010146 Labuhan Ruku Tahun Pembelajaran 2017/2018.

2.Untuk mengetahui pengaruh strategi pembelajaran ekspositori terhadap kemampuan membaca siswa kelas II SD Negri 010146 Labuhan Ruku Tahun Pembelajaran 2017/2018.

3.Untuk mengetahui ada atau tidak pengaruh model Students Facilitator and Explaining terhadap kemampuan membaca siswa kelas II SD Negri 010146 Labuhan Ruku Tahun Pembelajaran 2017/2018.

\section{Manfaat Penelitian}

Dengan tercapainya tujuan penelitian ini, penelitian ini bermanfaat sebagai berikut:

1. Dapat dijadikan dasar dalam rangka meningkatkan proses belajar mengajar khususnya membaca.

2. Sebagai pertimbangan tentang pemakaian model-model pembelajaran dalam bidang studi bahasa Indonesia yang melibatkan siswa aktif.

3. Sebagai bahan rujukan dan perbaikan bagi peneliti lainnya yang akan mengadakan penelitian lebih lanjut terhadap materi ini.

\section{METODOLOGI PENELITIAN}

Penelitian ini menggunakan metode eksperimen yang memberlakukan terhadap dua kelompok dalam bentuk pembelajaran. Kedua kelompok tersebut yang kemampuan awalnya sama dapat dicari dengan pre-tes (test awal), kemudian kedua kelompok tersebut diberi pengajaran kemampuan membaca. Untuk kelompok yang satu sebagai kelas eksperimen diberi pengajaran kemampuan membaca dengan menggunakan teknik ekspositori, kemudian diadakan post-test (test akhir). 
Metode ini memulai pengajaran membaca dan menulis dengan langkahlangkah sebagai berikut: (1) guru bercerita atau bertanya jawab dengan siswa disertai gambar, misalnya gambar keluarga yang terdiri dari bapak, ibu, budi, kakak. (2) membaca beberapa gambar, misalnya gambar ibu, gambar budi, gambar bapak, gambar kakak. (3) membaca kalimat dengan cara, meletakkan kalimat dibawah setiap gambar, ibu diberi kalimat: ini ibu budi.

Di bawah gambar anak laki-laki diberi kalimat ini budi dan seterusnya.Setelah anak dapat membaca kalimat dengan bantuan gambar, dilanjutkan dengan membaca kalimat tanpa gambar. (4) menganalisa sebuah kalimat menjadi kata, suku kata, dan huruf serta mensintesiskan kembali menjadi kalimat. Konsep upaya mengatasi kesulitan adalah suatu konsep yang berdiri sendiri, bila disepadankan dengan obyek kata tertentu yang memiliki makna kalimat, maka pengertiannya adalah suatu usaha atau ikhtiar yang mengarah ke lebih baik dari sebelumnya yang kurang baik, atau segala sesuatu yang telah melampaui batas tertentu sehingga diharapkan akan kembali secara wajar sesuai dengan standar yang sebenarnya. Sehingga pemberian makna dari konsep diatas akan lengkap bila dipadukan dengan obyek kalimat sesuai dengan apa yang menjadi sasaran dari maksud kalimat tersebut, dalam hal ini adalah konsep kesulitan dalam membaca (Hadisuparto, 1994: 34). Sebelum mengenal faktor-faktor penyebab kesulitan yang dihadapi siswa dalam belajar membaca, guru perlu mernahami konsep membaca dan aspek-aspek dalam membaca.

Dalam pelaksanaan pembelajaran membaca, guru seringkali dihadapkan pada siswa yang mengalami kesulitan, baik yang berkenaan dengan hubungan bunyi huruf, suku kata, kata, kalimat sederhana, maupun ketidakmampuan siswa memahami isi bacaan.Kesulitan membaca pada penelitian ini dititikberatkan pada masih kurangnya pengenalan terhadap jenis-jenis huruf. Berikut dikemukakan kesulitan-kesulitan yang umumnya dihadapi siswa dalam belajar membaca antara lain sebagai berikut. Kurang Mengenali Huruf Kesulitan yang sering dialami 
berupa ketidakmampuan siswa mengenali huruf-huruf dalam alfabetis masih sering dijumpai oleh guru. Ketidakmampuan siswa membedakan huruf besar dan kecil termasuk dalam kategori kesulitan ini.

Upaya yang ditempuh guru dalam membantu siswa yang mengalami kesulitan ini dapat berupa (1) huruf dijadikan bahan nyanyian, dan (2) menampilkan huruf dan mendiskusikan bentuk karakteristiknya khususnya huruf-huruf yang memiliki kemiripan bentu Membaca Kata demi Kata Siswa yang mengalami jenis kesulitan ini biasanya berhenti setelah membaca sebuah kata, tidak segera diikuti dengan kata berikutnya. Membaca kata demi kata seringkali disebabkan oleh; (a) gagal menguasai keterampilan pemecahan kode (decoding), (b) gagal memahami makna kata, atau (c) kurang lancar membaca.Membaca kata demi kata memang merupakan tahap awal dari kegiatan membaca.Akan tetapi jika siswa tidak mengalami kemajuan dalam hal tersebut, maka dia termasuk kategori siswa yang menghadapi masalah.Untuk memastikan apakah seorang siswa mengalami kesulitan tersebut dapat ditempuh melalui pengamatan. Cara yang dapat digunakan untuk mengatasi siswa yang mengalami jenis kesulitan ini adalah; (1) menggunakan bacaan yang tingkat kesulitannya paling rendah; dengan menyuruh siswa menulis kalimat dan membacanya secara keras, (2) Jika kesulitan ini disebabkan oleh kurangnya penguasaan kosakata, maka perlu pengayaan kosakata jika siswa tidak menyadari bahwa dia membaca kata demi kata, rekamlah kegiatan siswa membaca dan putarlah hasil rekaman tersebut.

Memparafrasekan yang Salah Dalam membaca, siswa seringkali melakukan pemenggalan atau berhenti membaca pada tempat yang tidak tepat atau tidak memperhatikan tanda baca, khususnya tanda koma. Jika kesulitan ini tidak diatasi, siswa akan mengalami banyak hambatan dalam proses membaca yang sebenarnya. Untuk mengatasi jenis kesulitan ini dapat digunakan beberapa cara berikut: (1) Jika kesalahan disebabkan oleh ketidaktahuan siswa terhadap makna kelompok kata (frasa), sajikan sejumlah kelompok kata dan latihan cara membacanya. (2) Jika 
kesalahan disebabkan oleh ketidaktahuan siswa tentang tanda baca, perkenalkan fungsi tanda baca dan cara membacanya. (3) Berikan paragraf tanpa tanda baca, suruhlah siswa untuk membacanya. (4) Selanjutnya ajaklah siswa-siswa untuk menuliskan tanda baca pada paragraf tersebut (Parowisastro, 1999: 37-41). Kesulitan Vokal Dalam bahasa Indonesia, beberapa vokal dilambangkan dalam satu huruf, mi alnya huruf [i] selain melambangkan bunyi [i] juga melambangkan bunyi [e] (dalam kata titik, kancil, dinding, dan sebagainya). Huruf [e] dapat melambangkan bunyi [e] (dalam kata sering, lebih, setengah dan sebagainya), juga melambangkan [e] (dalam kata kota Serang, selera, belerang, lentera, dan sebagainya), dan melamhangkan bunyi [e] (dalam kata deret, mobil derek, melek, cewek, dan sebagainya). Huruf-huruf yang melambangkan beberapa bunyi seringkali merupakan sumber kesulitan bagi siswa dalam membaca. Cara-cara berikut dapat digunakan untuk mengatasi kesulitan siswa dalam memahami dan mengucapkan bunyi vokal, yaitu: (1) Tanamkan pengertian dalam diri siswa bahwa huruf-huruf tertentu dalam melambangkan lebih dari satu bunyi, misalnya huruf [i] dapat melambangkan bunyi [i] dan [e], huruf [e] dapat melambangkan bunyi [e], [e], dan [e]. (2) Berikan contoh huruf [i] yang melambangkan bunyi [i] dan [e], huruf [e] yang melambangkan bunyi [e], [e], dan [e] dalam kata-kata. (3) Ajaklah siswa mengumpulkan kata yang di dalamnya terkandung huruf [i] yang melambangkan bunyi [i] dan [e], huruf [e] yang melambangkan bunyi [e], [e].

\section{HASIL DAN PEMBAHASAN}

Untuk memperoleh data dalam penelitian ini, penulis menggunakan tes esai. Dengan data itu diperoleh data untuk variabel X model Students Facilitator and Explaining dan data variabel kemempuan membaca sebagai variabel Y.

Setelah dilakukan penelitian tentang pengaruh model Students Facilitator and Explaining terhadap kemampuan membaca siswa kelas II SD NEGRI 010145 LABUHAN RUKU TAHUN PEMBELAJARAN 2017/2018 maka diperoleh hasil 
yaitu "terdapat perbedaan yang nyata pada kemampuan membaca siswa kelas". Hal ini dibuktikan berdasarkan perhitungan diketahui kemampuan sebagian siswa yang diajar dengan menggunakan model Students Facilitator and Explaining siswa banyak mendapatkan nilai 9 yaitu 36\%, artinya kemampuan sebagian besar siswa yang diajar dengan model students facilitator and explaining berada pada tingkat sangat baik. Sedangkan kemampuan membaca tanpa menggunakan model students facilitator and explaining siswa banyak mendapatkan nilai 7 sampai 8 artinya kemampuan dari sebagian besar siswa yang diajarkan tanpa model students facilitator and explaining berada pada tingkat baik.

\section{SIMPULAN DAN SARAN}

\section{Simpulan}

Berdasarkan temuan penelitian dan pembahasan ini dapat disimpulkan bahwa:

1. Rata-rata kemampuan membaca dengan menggunakan model Students Facilitator and Explaining adalah 6,7 dan digenapkan menjadi 7 Ini berarti kemampuan membaca dengan menggunakan model Students Facilitator and Explaining berada pada tingakat sangat baik dan diketahui siswa yang banyak mendapatkan nilai 9 yaitu $36 \%$.

2. Rata-rata nilai kemampuan membaca tanpa menggunakan model Students Facilitator and Explaining adalah 5,8 dan digenapkan menjadi 6. Ini berarti kemampuan membaca tanpa menggunakan model Students Facilitator and Explaining berada pada tingkat baik dan diketahui siswa banyak mendapatkan nilai 7 samapi 8 yaitu $40 \%$.

3. Terdapat perbedaan yang nyata antara kemampuan membaca oleh siswa kelas II SD yang diajar dengan menggunakan model Students Facilitator and Explaining di SD NEGRI 010146 LABUHAN RUKU Tahun Pembelajaran 2016/2017. Siswa yang diajar dengan menggunakan model Students Facilitator 
and Explaining lebih baik dari siswa yang diajar tanpa model Students Facilitator and Explaining dalam pembelajaran kemampuan membaca.

\section{Saran}

Sehubungan dengan hasil temuan penelitian di atas, maka yang menjadi saran penulis dalam penelitian ini sebagai berikut:

1. Guru bahasa Indonesia, disarankan agar menggunakan model yang sesuai dengan materi pengajaran sehingga peroses belajar mengajar dapat berjalan dengan efektif.

2. Siswa disarankan, untuk selalu lebih efektif mengikuti kegiatan belajar mengajar yang selama ini dilaksanakan, serta lebih aktif membaca yang nantinya akan menambah wawasan dan ilmu pengetahuan siswa.

3. Agar dilakukan penelitian lanjutan kemampuan membaca dengan model Students Facilitator and Explaining dan model belajar lainnya. 


\section{DAFTAR PUSTAKA}

Tarigan, Henry Guntur. 2008. Membaca Sebagai Suatu Keterampilan Berbahasa. Angkasa. Bandung.

Depdikbud.(1992). Petunjuk Teknis Pengajaran Membaca di Sekolah Dasar. Jakarta: Depdikbud Mueller, Stephanie. (2006). Panduan Belajar Membaca Jilid 1 dengan Bendabenda di Sekitar Kita untuk Siswa usia 3-8 Tahun. Jakarta: Erlangga for Kids.

Rahim, Farida. (2007). Pengajaran Membaca di Sekolah Dasar. Jakarta: PT Bumi Aksara Slamet, St. Y. (2007). Dasar-dasar Pembelajaran Bahasa dan Sastra Indonesia di Sekolah Dasar. Surakarta: LPP UNS dan UNS Press.

Hariyanto, Agus. 2009. Membuat Anak Anda Cepat Pintar Membaca!: Panduan dan Metode Penerapannya. Yogyakarta: DIVA Press.

Indriana, Dina. 2011. Ragam Alat bantu Media Pengajaran. Yogyakarta: Diva Press. 